\title{
COLLECTING FOSSILS
}

POJETA, John, Jr., U.S. Geological Survey, MRC 137, Rm. E-308, Museum of Natural History, Smithsonian Institution, Washington, DC 20560, U.S.A.

Almost all of us who collect fossils can agree on two points: (1) In order to collect we need the permission of the person in charge of the locality, and (2) Over the past 20 years, collecting fossils has become increasingly complicated. Beyond these truths, almost every collector has her/his perspectives on the proper do's and don't's of the process. These points of view range from, (1) Only professional paleontologists should be allowed to collect fossils to, (2) Everyone should be allowed to collect fossils.

In the 16 years that $I$ have been involved in discussions about "Land Access Issues in Paleontology," we have repeatedly discussed the following items. (1) What is a professional paleontologist? (2) Is Federal legislation needed? (3) Is a permit system needed? (4) To whom do the fossils belong? (5) What is commerce in fossils? (6) Are vertebrate fossils special? (7) How do we eliminate public confusion of paleontology with archeology? (8) How does one determine the scientific value of a fossil? (9) Who should be allowed to collect? (10) Should people be fined and/or jailed for collecting fossils? (11) What are the problems of land managers?

In my opinion, we need to give all those interested in fossils--professionals, amateurs, suppliers, and miners and quarrypersons a process by which they can pursue their interests.

These and other issues in collecting fossils have been discussed by relatively small committees, panels, and the like. They have not been discussed by a broad spectrum of paleontologists. This symposium should provide such a forum for paleontology and all attendees should leave with new perspectives and knowledge to discuss the issues.

Fossil collecting is a subset of the larger issues of natural history collecting and scientific studies on the public lands in general. For some time, entomologists and malacologists have expressed considerable concern about restrictions on collecting insects and mollusks.

In May 1995, the National Research Council (NRC) held a planning meeting on these larger issues. Those who attended the meeting study ecology, oceanography, volcanology, paleontology, geophysics, political science, rural sociology, forestry, and land policy. Among other things, we discussed drilling into a volcano in Katmai National Park, seismic reflection studies at Lake Mead, and the Mount Graham telescope. All these nonpaleontological studies involved difficulties with land access or the endangered species act. To date, the NRC has not been able to find funding to convene a panel to recommend guidelines to land managers.

As an interest group, scientists must become far more active in addressing the issue of land access for all kinds of studies. Do scientists have a vehicle or method for providing information to land managers, elected officials, and other decision makers? Can the disparate and often fractious scientific organizations speak with a unified voice so that we do not confuse decision makers? We must organize ourselves to protect the right to collect natural history objects, including fossils, for our studies. 